ROCZNIKI PEDAGOGICZNE

Tom 11(47), numer specjalny - 2019

DOI: http://dx.doi.org/10.18290/rped.2019.11s-16

JUSTYNA KOPCZYŃSKA-WISZ

\title{
WSPÓŁCZESNE PROBLEMY RESOCJALIZACJI
}

Współcześnie resocjalizacja stała się bardzo szerokim obszarem działań przedstawicieli różnych dziedzin. Nic w tym dziwnego, gdyż aby była efektywna musi się rozwijać, nadążać za szerzącą się przestępczością, jej formami oraz sprawcami. Bo to właśnie ludzie i popełniane przez nich przestępstwa determinują powstawanie i rozwój procesu modyfikacji osobowości jednostki społecznej w celu przystosowania jej do życia w społeczeństwie.

Czyn przestępczy prowadzi do wymiaru sprawiedliwości, a w konsekwencji bardzo często do pobytu w zakładzie karnym lub poprawczym. Tutaj skazany spotyka się z zupełnie nową rzeczywistością. Poddany zostaje procesom depersonalizacji, degradacji, standaryzacji i stygmatyzacji. Proces depersonalizacji związany jest z zawieszeniem wszelkich planów życiowych, rodzinnych i zawodowych. Osoba skazana pozbawiona jest możliwości dokonywania zmian w swoim życiu w sposób dobrowolny. Jej codzienne działania i obowiązki formułuje personel więzienny. $Z$ kolei proces degradacji ma miejsce $\mathrm{z}$ chwilą znalezienia się skazanego w sytuacji poniżenia bądź znieważenia jego godności osobistej. Osoby skazane podlegają również procesowi standaryzacji, który jest wynikiem obowiązujących przepisów wobec osób pozbawionych wolności. Jednakowy dla wszystkich regulamin, niekiedy też ubiór, sposoby zaspokojenia potrzeb stwarzają poczucie zagrożenia dla indywidualnego charakteru każdego człowieka. Także proces stygmatyzacji deprecjonuje wartość godności skazanego. Jest on traktowany zarówno w więzieniu, jak i na wolności jako przestępca (Iwański, 2017; por. Pierzchała, 2013).

Czym zatem jest resocjalizacja? Resocjalizacja jest procesem powtórnej socjalizacji osób niedostosowanych społecznie, a więc przyjęcia przez nie

Mgr Justyna KopczyŃSKa-Wisz - doktorantka Uczelni Łazarskiego, ul. Świeradowska 43, 02-662 Warszawa; e-mail: j_kw@op.pl 
takiego stylu życia, który nie narusza norm prawnych i moralnych powszechnie uznanych i akceptowanych przez społeczeństwo.

Zbigniew Iwański twierdzi, że resocjalizacja zajmuje się wychowaniem osób niedostosowanych społecznie. Jako nauka specjalistyczna w zakresie pedagogiki podejmuje się działań wychowawczych i terapeutycznych, by przywrócić osoby dysfunkcjonalne społecznie do samodzielnego i odpowiedzialnego życia. W centrum uwagi wychowawców powinien być człowiek, jako podmiot, wobec którego podejmowany jest proces wtórnej socjalizacji (Iwański, 2017). Resocjalizacja powinna obejmować zróżnicowaną metodykę postępowania $\mathrm{z}$ wychowankiem. Jej niezbędnym elementem jest prowadzona równolegle profilaktyka w zakresie uzależnień, agresji, przemocy. Udział znajomych i bliskich w procesie wychowawczym zajmuje pierwszorzędne miejsce, dodatkowo wzmacniając motywację wychowanka do zmiany swego dotychczasowego postępowania, jak również przyczynia się do skuteczności resocjalizacji i zmniejsza zjawisko recydywy.

Zdaniem Brunona Hołysta efektywność resocjalizacji jest zdeterminowana różnymi czynnikami, do których należą: kondycja biologiczna (wiek, płeć, stan zdrowia, wygląd, motoryka), kondycja psychiczna, kondycja intelektualna, kondycja społeczna oraz kondycja ekonomiczna. Resocjalizacja zatem musi oznaczać socjoterapię przyczynową jako ten rodzaj oddziaływania, który ma szansę na ukształtowanie świadomej i utrwalonej postawy otwartej na niekonfliktowe, a przynajmniej na nienaruszające zasad prawnych rozwiązywanie problemów życiowych (Hołyst, 2017, s. 17).

Skuteczna resocjalizacja wymaga zespołowego współdziałania wszystkich podmiotów biorących udział w pracy wychowawczej ze skazanymi. Nie może tu zabraknąć wychowawców, pedagogów, psychologów, rodziców, bliskich i znajomych wychowanków, a także przedstawicieli grup społecznych, zawodowych i wyznaniowych. Proces resocjalizacji dokonuje się w klimacie wychowawczym, który tworzą: osoby wychowujące, osoby wychowywane oraz warunki determinujące przebieg i strukturę procesu wychowawczego. Taki proces prowadzony w zakładzie penitencjarnym ma określony cel, pedagogiczno-psychologiczne podstawy teoretyczne i jest oparty na wnikliwej diagnozie, która obejmuje nie tylko etiologię przestępstwa skazanego, lecz także jego predyspozycje i umiejętności do współpracy w kształtowaniu własnego charakteru i postaw prospołecznych.

Priorytetową funkcją placówek penitencjarnych jest resocjalizacja skazanych, dlatego istotne jest dysponowanie profesjonalnym personelem wychowawczym, którego zadaniem jest zorganizowanie i realizowanie zindywidualizowanego programu resocjalizacyjnego. Żaden jednak zakład karny nie jest w stanie 
wywołać u skazanego pożądanych zachowań, jeśli osoba taka nie ma kontaktu $\mathrm{z}$ rodziną, która odgrywa bardzo istotną rolę $\mathrm{w}$ procesie readaptacji społecznej. Kontakt z rodziną sprawia, że skazani podtrzymują pozytywny obraz samego siebie, odnoszą satysfakcję emocjonalną oraz nabywają przekonania, że nadal są potrzebni swoim bliskim. Dla wielu osadzonych rodzina i kontakt z najbliższymi to jedyne ogniwa łączące świat „ludzi wolnych” ze światem osób żyjących w izolacji. Resocjalizacja winna być oparta na personalistycznym traktowaniu wychowanka. Bez względu na dokonywane przez niego czyny nie przestaje on być człowiekiem. Każdy ma szansę zweryfikować swoje postępowanie i zacząć żyć według obowiązujących zasad i norm społecznych (Iwański, 2017).

$\mathrm{Na}$ efektywność resocjalizacji mają niewątpliwie wpływ oddziaływania terapeutyczne, indywidualne bądź grupowe. Jako przykład takich oddziaływań Marek Konopczyński wymienia teatr resocjalizacyjny, wskazując na jego terapeutyczną wartość, podkreślając także terapeutyczne i korekcyjne właściwości sportu, działalności artystycznej itp. Wyróżnia terapię przez muzykę (muzykoterapia), którą charakteryzuje jako sposób wspomagający resocjalizację osób nieprzystosowanych społecznie (Konopczyński, 2006; por. Pierzchała, 2018a).

Podejmowane w praktyce formy oddziaływań resocjalizacyjnych muszą obejmować wielowymiarowe aspekty dokonywanych przestępstw przez sprawców, uwzględniając specyfikę ich sytuacji życiowej, psychicznej, a nawet psychoseksualnej. Celowe jest to, aby oddziaływania takie zminimalizowały ryzyko ponownego popełnienia czynów karalnych, a także, w przypadku sprawców skazanych na bezwzględną karę pozbawienia wolności, umożliwiły skuteczny powrót skazanego do społeczeństwa, dotychczasowego środowiska, w którym żył, po zakończonym odbywaniu kary, poprzez zredukowanie niekorzystnych konsekwencji długotrwałej izolacji w postaci prizonizacji, akulturacji i dekulturacji.

Aby móc orzec, jakie potrzeby kryminogenne ma dany sprawca, jaki jest poziom ryzyka powrotu do przestępstwa oraz jakie są jego możliwości poznawcze, należy skorzystać z dostępnych narzędzi diagnostycznych, najlepiej tych, których skuteczność prognostyczna została dowiedziona w licznych badaniach (Chojecka, 2013).

Skuteczność metod kognitywno-behawioralnych opiera się na dwóch zasadach: na zasadzie „relacji” (zależności), która gwarantuje szacunek oraz odpowiedni klimat w pracy z „,klientem”, oraz na zasadzie „ustrukturyzowania”, która zakłada, że zmiany w kierunku przyjęcia prospołecznych postaw odbywają się poprzez odpowiednie modelowanie, wzmacnianie oraz kształtowanie umiejętności rozwiązywania problemów (Bonta, Andrews, 2007).

Podstawowym warunkiem osiągnięcia jakichkolwiek rezultatów jest wytworzenie odpowiedniej motywacji u sprawców, wobec których podejmowane 
będą projektowane działania (Kowalczyk, 2012). Na ogół zakłada się bowiem, że celem wychowania resocjalizacyjnego jest całościowe ujęcie perspektywy rozwojowej człowieka nieprzystosowanego społecznie w jego wymiarach osobowych i pełnionych ról i to ujęcie jest podstawą wszelkich oddziaływań pedagogicznych. Uczynienie człowieka z jednej strony podmiotem życia, a z drugiej przystosowanie go do innych podmiotów (ludzi), sytuacji i zdarzeń jest w gruncie rzeczy zadaniem socjalizacyjnym. Celem tradycyjnego wychowania resocjalizacyjnego jest wspomaganie procesów socjalizacji, a tam, gdzie nie spełniają one swej roli lub socjalizacja przebiega nieprawidłowo, dokonanie wychowawczych korekt, modelowań i uzupełnień (Konopczyński, 2012). Wobec sprawców ze zdiagnozowanym wysokim poziomem agresji zalecany będzie udział w formach treningowych redukujących skłonności agresywne, natomiast modyfikacji zaburzonej samooceny służyć może udział w formach treningowych przywracających adekwatną samoocenę.

Zdaniem Zbigniewa Iwańskiego gwarantem prawidłowego przebiegu procesu resocjalizacji jest zawsze osoba wychowawcy. Pożądanymi cechami są w tym przypadku odpowiedni charakter, właściwa kompetencja, autorytet wynikający ze sprawiedliwego traktowania wszystkich wychowanków oraz dobry stan zdrowia fizycznego i psychicznego (Iwański, 2017). Każdy wychowawca, osoba, która resocjalizuje, pracuje z wychowankiem w inny sposób, gdyż każda z tych osób jest inna. Rządzimy się jednymi prawami, one stanowią niejako podstawę działania, jednak narzędzia, jakimi posługują się specjaliści, są wielorakie. Tu ogromną rolę odgrywa również doświadczenie oraz elastyczność w stosowaniu metod. Praca z różnymi „przypadkami” uczy bowiem, jakie postępowania są skuteczne względem jakich osób. Każdy wychowawca reprezentuje inną osobowość i własny styl pracy. Każdy ma określony zasób wiedzy oraz doświadczenie, co stanowi o możliwości wyboru zindywidualizowanych metod wychowawczych.

W procesie resocjalizacji ważny jest stosunek do drugiego człowieka. Powinien on być wyrażony szacunkiem, chęcią niesienia pomocy. U wychowanków najczęściej zaburzona jest ich sfera osobowości. Przejawia się ona niewłaściwymi z punktu widzenia oceny społecznej relacjami międzyludzkimi. Istotny w pracy resocjalizacyjnej jest stosunek wychowanka do samego siebie. Musi on sam chcieć pracować nad sobą, podejmować wysiłek samowychowawczy (Iwański, 2003).

Nie budzi wątpliwości fakt, że każdy człowiek ma swoją wartość, bez względu na rolę i miejsce w społeczeństwie. Kara pozbawienia wolności nie wpływa na zmianę zachowania jednostki w taki sposób, by była ona odpowiedzialna i zarazem samodzielna. Należy zatem tak resocjalizować, by osoba poddawana działaniom wychowawców miała jasno sprecyzowane, czego się od niej wymaga, jakie są oczekiwania, ale również miała świadomość własnej godności. 
Ważne ogniwo w pracy resocjalizacyjnej z osobami niedostosowanymi społecznie stanowi kuratela sądowa. Kuratorzy sądowi realizują określone przez prawo zadania o charakterze wychowawczo-resocjalizacyjnym, diagnostycznym, profilaktycznym i kontrolnym. Poprzez ich realizację dostarczają sądowi informacji o osobie, wobec której sąd wydaje orzeczenie, i stwarzają warunki minimalizujące symptomy patologii społecznej (Jedynak, 2007). Wykonują oni swoje zadania w środowisku podopiecznych, jak również na terenie zamkniętych zakładów i placówek. Pedagogika resocjalizacyjna oraz psychologia wyznaczają kuratorowi sposób posługiwania się środkami prawnymi. Zalicza się do nich: wskazywanie motywacji zachowania prospołecznego, respektującego powszechnie uznawane normy moralne, pobudzenie aktywności dozorowanego w samodzielnym, osobistym załatwianiu swoich spraw i wyzwalania własnej inicjatywy, pomoc w rozwiązywaniu problemów przerastających możliwości własne dozorowanego (Śpiewak, 1999).

Zdaniem Andrzeja Bałandynowicza

[...] probacja jako środek resocjalizacji w oparciu o społeczeństwo bazuje na teorii, że najlepszy sposób osiągnięcia celu, jakim jest resocjalizacja, to organizowanie sankcji kryminalnych w społeczeństwie w przypadkach, gdy uzasadniają to funkcje kary. Zakłada się, że dana osoba nauczy się z powodzeniem żyć w społeczeństwie, a nie w sztucznym i oderwanym środowisku, jakim jest instytucja więzienna. Probacja jako środek resocjalizacji w oparciu o społeczeństwo, w połączeniu z sensownym zaangażowaniem społecznym, zapewnia wymagane oddziaływanie społeczne, ekonomiczne oraz osobowościowe (Bałandynowicz, 2006).

Autor ten podkreśla, że w centrum działań wychowawczych stoi konkretny człowiek, którego należy traktować w sposób podmiotowy ze względu na jego niezbywalną godność, wynikającą z natury ludzkiej. Bałandynowicz twierdzi, że w ustawodawstwie karnym dominującą karą jest pozbawienie wolności, natomiast jedynie marginalne znaczenie mają środki probacyjne. Trzymanie się kar izolacyjnych, jako skutecznych w resocjalizacji osadzonych, staje się mitem i nie przynosi skuteczności w zmianie ich postaw i zachowań. Jednostki penitencjarne ograniczają w znacznym stopniu zaspokajanie potrzeb skazanych. Widoczny staje się element deprywacyjny kary. Zaznacza się pojawienie agresji, obniżona zostaje sprawność fizyczna i psychiczna izolowanych, pojawiają się stany lękowe i stałe poczucie zagrożenia. Właściwym działaniem na rzecz osób objętych resocjalizacją jest koncepcja ujmowania człowieka całościowo - holistycznie (Iwański, 2017).

Współczesna rzeczywistość penitencjarna wiąże się z wieloma, częstokroć bardzo złożonymi problemami. Wśród najczęstszych wymienia się: przepełnienie 
(przeludnienie zakładów karnych), brak pracy w okresie izolacji penitencjarnej czy też demoralizujący nadmiar czasu wolnego. Czynniki te, powodujące wiele niekorzystnych następstw, utrudniają skazanym odbywanie kary pozbawienia wolności, prowadząc niejednokrotnie do wielu negatywnych zachowań, zaś funkcjonariuszom utrudniają pracę z osadzonymi, co w rezultacie nie sprzyja procesowi resocjalizacji (Łuczak, 2016).

Przeludnienie wymieniane jest często jako pierwszoplanowy i największy problem polskiego więziennictwa. Nic dziwnego, gdyż generuje ono wiele niekorzystnych następstw zarówno o charakterze bezpośrednim, jak i pośrednim. Ograniczając swobodę poruszania się, dostępu do różnych urządzeń (utrzymanie ładu i porządku), działa konfliktogennie na relacje ze współwięźniami i w rezultacie nie sprzyja prospołecznym zachowaniom skazanych ani też pozytywnym efektom resocjalizacji. Utrudnienia te w szczególny sposób są odczuwane przez osoby z długoterminowym wyrokiem kary pozbawienia wolności. Przepełnione cele stwarzają również duże utrudnienie w pracy personelu więziennego, uniemożliwiając często należyte wypełnianie obowiązków, gdyż pracownicy nie są w stanie na bieżąco interweniować w przypadku zaistnienia nieprawidłowości.

Zjawisko przeludnienia obniża niejednokrotnie skuteczność procesu resocjalizacji również z tego względu, że bywa przyczyną większego oddalenia skazanych od miejsca zamieszkania. Sytuacja ta stwarza dodatkową barierę, gdyż utrudnia lub całkowicie uniemożliwia kontakt z najbliższymi osobami (Łuczak, 2016).

Zatrudnienie w życiu każdego człowieka odgrywa bardzo ważną rolę, zapewniając dochód, wypełniając czas, rozwijając zainteresowania i pasje czy wreszcie dostarczając satysfakcji, to jednak znaczenie pracy w rzeczywistości penitencjarnej jest jeszcze większe. Praca spełnia ważną funkcję poprawczą i readaptacyjną: uczy i utrwala u osadzonych umiejętności uczciwego utrzymywania się po zwolnieniu z zakładu karnego. Pozwala nie tylko przetrwać monotonię zamknięcia, ale również, dzięki nabyciu nowych umiejętności, zwiększa szansę na zatrudnienie poza murami więziennymi. Praca zaspokaja wiele potrzeb społecznych człowieka, dlatego też wykonywanie jej w okresie izolacji więziennej jest traktowane jako podstawowy środek resocjalizacji penitencjarnej (Łuczak, 2016).

Czas wolny pełni niezwykle ważną rolę w resocjalizacji skazanych. Przede wszystkim dlatego, że osadzeni mają go przeważnie bardzo dużo. Z jednej strony może mieć on charakter konstruktywny, gdy jest wypełniony wartościowymi zajęciami, z drugiej zaś - destruktywny, jeśli towarzyszy mu bezczynność, nuda bądź też angażowanie się w różnego rodzaju formy związane ze zjawiskiem podkultury więziennej. Czas wolny jest często postrzegany jako stracony; skazani chcieliby go jak najszybciej wykreślić ze swojego życia. Poczucie ciężaru tak wolno 
upływającego czasu i związana z nim nuda wywołują u skazanych lęk spowodowany niekorzystną zmianą ich osobowości i obawą zakłóconych relacji w kontaktach społecznych po opuszczeniu środowiska więziennego (Łuczak, 2016).

Nadmiar czasu wolnego staje się problematyczny nie tyle ze względu na ograniczenia związane ze strukturą organizacyjną zakładu lub niedostatki bazy materialno-wyposażeniowej, ile z powodu braku umiejętności jego wykorzystania. Skazani nie traktują czasu wolnego jako wartości, którą mogą wykorzystać w określonym celu (np. samorozwoju, rekreacji), lecz jako coś, co trzeba przeżyć, i to w miarę szybko i niepostrzeżenie (Łuczak, 2014).

W preferowanych obecnie metodach oddziaływań resocjalizacyjnych przywiązuje się bardzo dużą wagę do lepszego i bardziej efektywnego wykorzystywania czasu wolnego skazanych. Kładzie się zwłaszcza nacisk na stosowanie metod twórczej resocjalizacji opartych na założeniach psychologii poznawczej, której przedstawiciele podkreślają szczególną rolę cech jednostki oraz jej umysłowego potencjału. W tych to metodach upatruje się obecnie możliwości stymulacji samorozwoju i pozytywnych przemian osobowości skazanych (Łuczak, 2016).

Zdaniem Sławomira Sobczaka wychowanie resocjalizacyjne musi opierać się na określonym systemie wartości, i to takim, który jest zgodny z obowiązującymi normami życia społecznego. Instytucje resocjalizujące powstają po to, by służyć człowiekowi, który został uznany za niedostosowanego społecznie na skutek naruszania zasad i norm funkcjonujących w społeczeństwie (Iwański, 2017).

Trening redukujący zachowania agresywne jest bardzo przydatnym narzędziem w resocjalizacji ze względu na swe wielowymiarowe korzyści. W programie tym wykorzystuje się założenia terapii behawioralno-poznawczej. W trakcie powziętych oddziaływań dokonuje się modyfikacji deficytów interpersonalnych (wynikających $\mathrm{z}$ braku umiejętności zachowania się w wielu sytuacjach i zwykle zastępowaniu braku kompetencji zachowaniem agresywnym), zaburzeń emocjonalnych (polegających na zachowaniach impulsywnych i niedostatecznej kontroli gniewu i złości) oraz zaburzeń poznawczych (związanych z brakiem zdolności zrozumienia sytuacji, w jakiej aktualnie znajduje się jednostka, i brakiem umiejętności przewidywania konsekwencji swoich zachowań) (Kowalczyk, 2012).

Obecnie ustawodawca wzbogacił możliwości pracy ze sprawcami przemocy, wymagającymi resocjalizacji ze względu na brak panowania nad agresją, o programy korekcyjno-edukacyjne. Podstawę prawną do realizacji programów korekcyjno-edukacyjnych dla osób stosujących przemoc w rodzinie stanowi art. 6 ust. 4 pkt 2 ustawy z dnia 29 lipca 2005 r. o przeciwdziałaniu przemocy w rodzinie (Dz. U. nr 180, poz. 1493). Program ten ma charakter edukacyjno-korekcyjny. 
W części edukacyjnej skoncentrowany jest na przekazaniu szeroko pojętej wiedzy na temat zjawiska przemocy, część korekcyjna ukierunkowana jest na zdobycie umiejętności niestosowania przemocy, trening umiejętności społecznych i asertywności oraz naukę konstruktywnego rozwiązywania sporów i korzystania ze wsparcia społecznego. Jednym z głównych założeń programu jest pomoc sprawcom w zaprzestaniu stosowania przemocy poprzez edukację, która ma na celu uświadomienie sprawcy, czym jest przemoc, uzyskanie przez niego świadomości własnych zachowań przemocowych wobec bliskich, rozpoznanie sygnałów ostrzegawczych zapowiadających zachowania przemocowe, opracowanie „planu bezpieczeństwa” zapobiegającego użyciu siły i przemocy oraz nabycie nowych umiejętności służących rozwiązywaniu konfliktów, sporów w rodzinie bez użycia agresji, jak również naukę umiejętności partnerskiego układania stosunków w rodzinie, uczenie się korzystania z pomocy innych oraz naukę umiejętności konstruktywnego wyrażania uczuć (por. Pierzchała, 2018b).

Jak wynika ze statystyk, skłonność do stosowania przemocy jest immanentną cechą wielu podopiecznych poddawanych resocjalizacji - zarówno tych odbywających karę pozbawienia wolności w warunkach izolacji penitencjarnej, jak i tych z warunkowym zawieszeniem jej wykonania. W związku z powyższym niezbędne jest poddanie ich oddziaływaniom redukującym tego typu zachowania. Należy wsłuchiwać się w potrzeby człowieka, by ułatwić mu pokonanie trudności i rozwiązanie życiowych problemów. Człowiek - bez względu na swoją pozycję społeczną czy zawodową - dąży do określonego celu. W swoich wyborach opiera się na doświadczeniach, kierując się akceptowanym przez siebie systemie wartości. Przestępca - bez względu na swoje czyny - nie przestaje odczuwać, myśleć, marzyć.

Jednym z zagrożeń dla skutecznej resocjalizacji więziennej jest subkultura więzienna, rozumiana jako alternatywa dla resocjalizacji. Encyklopedia popularna $P W N$ ujmuje podkulturę jako „wzory, normy, itp. obowiązujące w grupie społecznej stanowiącej część szerszej zbiorowości, odmienne od obowiązujących ogół społeczeństwa" (s. 596). Ogólnie rzecz biorąc, subkultura to nieformalna grupa osób działająca według odrębnych wzorców postępowania, najczęściej sprzecznych z przyjętymi zwyczajowo normami społecznymi. Subkultury są hermetycznie zamknięte dla osób z zewnątrz. Mają silne poczucie wewnętrznej więzi. Członkowie tych grup to zwykle ludzie silnego charakteru, którzy stosują przemoc fizyczną względem innych współosadzonych. Przemoc ta przyjmuje różne formy, zdarzają się m.in. gwałty homoseksualne, napady, a nawet zabójstwa. Inną formą przemocy ze strony tzw. grypsujących jest poniżanie, któremu mogą towarzyszyć wyzwiska, pogarda, obnażanie słabości tych, wobec których jest ona stosowana. Zdarzają się również kradzieże, oszustwa, wymuszenia. 
Grupa grypsujących charakteryzuje się dynamizmem, ma własny system komunikacji, swoich przywódców, własny kodeks postępowania, swoje określone wartości. W żadnym wypadku nie może do niej przystąpić przedstawiciel wymiaru sprawiedliwości ani skazany za przestępstwa seksualne. Tacy w opinii „grypsery” zasługują na pogardę i poniżenie (Przybyliński, 2006).

Jak wyżej wskazano, przejawem subkultury więziennej jest powstawanie przestępczości w zakładach karnych, co stanowi zasadniczy problem dla całego procesu resocjalizacji skazanych. Subkultura, tzw. drugie życie, niesie ze sobą wyzwania dla realizujących proces resocjalizacji w więzieniach. Znajomość wiedzy pedagogicznej i psychologicznej nie wystarcza, by skutecznie podejmować działania wychowawcze. Potrzebna jest znajomość funkcjonowania subkultury więziennej. Poznanie jej mechanizmów, struktury, zasad i norm ułatwia zrozumienie przebiegu życia skazanych w warunkach izolacji.

Sporym utrudnieniem i wyzwaniem dla resocjalizacji jest zjawisko stygmatyzacji, czyli niechęć i obawa wobec powracających skazanych (Pierzchała, 2016; 2017a). Społeczność bowiem z wielką rezerwą odnosi się do powracających na wolność jednostek. Utrudnienia w znalezieniu przez nich pracy mogą powodować powstanie recydywy.

Pojęcie recydywy jest różnie rozumiane w zależności od celu rozpatrywania zjawiska i dlatego mówi się o recydywie: kryminologicznej, penitencjarnej i jurydycznej. O recydywie kryminologicznej mówimy, gdy jednostka ponownie popełnia przestępstwo i bez znaczenia pozostaje to, czy za poprzednio dokonany czyn była skazana, czy odbyła całą lub część kary oraz ile czasu upłynęło od jej odbycia. Kryterium zasadniczym i jedynym jest popełnienie przestępstwa kolejny raz (por. Pierzchała, 2017b, s. 91-117). Z punktu widzenia kryminologii nie jest istotne zachowanie przestępcze, ale pewien proces, czyli swego rodzaju ciągłość tego rodzaju podobnych zachowań. Jest to bardzo szerokie rozumienie recydywy, które implikuje pewne niebezpieczeństwo dla praktyki prawno-resocjalizacyjnej. Zaciera się bowiem różnica między przestępcami mniej i bardziej zdemoralizowanymi, uporczywie podejmującymi zachowania przestępcze i tymi, którzy popełniają przestępstwa sporadycznie.

Znacznie węższe znaczenie recydywy zawiera ujęcie jurydyczne (recydywa prawnokarna, kodeksowa). Ujęcie prawnokarne odnosi się do sfery wymierzania kary i dlatego obwarowane jest wyraźnymi przesłankami. Według przepisów prawa nie każdy, kto popełnia kolejne przestępstwo, działa w warunkach recydywy. Każde z popełnionych przez recydywistę przestępstw musi spełniać określone w Kodeksie wymagania: pierwsze z popełnionych przez recydywistę przestępstw musi być przestępstwem umyślnym, a sprawca musi za to przestępstwo być skazany na karę pozbawienia wolności, której musi odbyć 
co najmniej sześć miesięcy. O recydywie możemy mówić dopiero wtedy, gdy sprawca skazany za przestępstwo (i na warunkach opisanych wyżej) popełnia kolejne. Drugie przestępstwo musi być również przestępstwem umyślnym. Dodatkowo musi to być przestępstwo podobne do przestępstwa, za jakie sprawca został skazany wcześniej (Malec, 2017).

W większości współczesnych państw, również w Polsce, systemy wykonywania kary pozbawienia wolności są oparte na zasadach progresji i indywidualizacji postępowania ze skazanym. Resocjalizacja więzienna odbywa się za świadomą zgodą osadzonego i jest jego prawem, nie obowiązkiem. Jest to o tyle korzystne, że sprzyja względnej otwartości skazanego i jego gotowości na zmiany, których sam może dokonywać.

Wychowawcza organizacja kary pozbawienia wolności uzależniona jest od typu i rodzaju zakładu karnego, w jakim skazany przebywa. W polskim systemie penitencjarnym obowiązują określone klasyfikacje zakładów karnych, skazanych oraz systemu wykonywania kary pozbawienia wolności. Pierwszym czynnikiem różnicującym osadzonych jest rodzaj zakładu karnego ze względu na formalnoprawne właściwości osadzonych (Malec, 2017). Literą R oznaczony jest zakład karny dla recydywistów penitencjarnych. Zgodnie z art. $86 \S 1$ k.k.w. „w zakładzie karnym dla recydywistów penitencjarnych odbywają karę dorośli skazani za przestępstwo umyślne na karę pozbawienia wolności lub zastępczą karę pozbawienia wolności oraz ukarani za wykroczenia umyślne karą aresztu lub zastępczą karą aresztu, którzy uprzednio już odbywali takie kary lub karę aresztu wojskowego za umyślne przestępstwa lub wykroczenia, chyba że szczególne względy resocjalizacyjne przemawiają za skierowaniem ich do zakładu karnego dla odbywających karę po raz pierwszy". Zgodnie z § 2 tego samego artykułu w zakładzie karnym, o którym mowa w $\S 1$, mogą odbywać karę skazani określeni w art. 65 Kodeksu karnego, czyli tacy, którzy uczynili z przestępstwa stałe źródło dochodu, bądź też działając w zorganizowanej grupie lub związku mającym na celu popełnienie przestępstwa oraz wobec sprawcy przestępstwa o charakterze terrorystycznym. W zakładzie karnym dla recydywistów mogą ponadto zostać osadzeni sprawcy, o których mowa w art. $37 \S 1$ pkt 2 i 5 k.k.s., którzy uczynili sobie z popełniania przestępstw skarbowych stałe źródło dochodu, bądź też popełnili przestępstwo skarbowe, działając w zorganizowanej grupie albo w związku mającym na celu popełnienie przestępstwa skarbowego.

Przeszkodą w resocjalizacji jest również często spotykany fakt, że środowiska rodzinne skazanych są dotknięte patologią. Alkoholizm, narkomania, bezrobocie, prostytucja mają tam swoje miejsce bytu. Taka sytuacja powoduje u skazanych, którzy wyszli na wolność, frustrację i brak wiary w możliwość funkcjonowania 
w społeczeństwie w sposób nienaruszający prawa. Czując się niepotrzebni i nieakceptowani, wracają do społeczności przestępczej, która ich zna i rozumie. Należy im pomóc i przygotować społeczeństwo na pojawienie się skazanego po odbyciu kary więzienia. Osoby powracające $\mathrm{z}$ więzienia oczekują na danie im szansy włączenia się w aktywne życie społeczne. Izolowanie ich od społeczeństwa, utrudnienia w znalezieniu miejsca pracy spycha ich na margines życia.

Stygmatyzacja byłych przestępców jest sprzeczna z humanizacją człowieka. Stawia ich w sytuacji odrzucenia przez środowisko, w którym wzrastali i gdzie są ich bliscy i znajomi. Człowiek bowiem jest istotą społeczną. Jego życie jest oparte na wzajemnych korelatach międzyludzkich. W naturze ludzkiej tkwi pragnienie bycia z innymi, a sam człowiek w pojedynkę nie potrafi rozwijać się i żyć, dlatego społeczeństwo nie może zamknąć się na powracających z więzienia. Stosowanie właściwych metod wychowawczych przy współpracy zarówno społeczeństwa, jak i samego skazanego może przyspieszyć jego readaptację społeczną. W przeciwnym razie skazany powróci na drogę przestępczą.

Recydywiści są najtrudniejszym przedmiotem resocjalizacji, gdyż łatwo adaptują się do warunków zakładu karnego i łączą się w zhierarchizowane grupy nieformalne (Iwański, 2017). Recydywa stanowi znaczący problem dla resocjalizacji skazanych. Narastająca fala przestępstw jest wynikiem braku skutecznych metod, które są stosowane w dotychczasowym systemie wychowawczym. Również niewystarczająco dobrze przygotowana kadra pedagogiczna wpływa niekorzystnie na zmianę zachowań i postaw jednostek objętych oddziaływaniem resocjalizacyjnym. Społeczeństwo nie jest także dobrze zorientowane w polityce karnej państwa, stąd też niechętnie odnosi się do samych skazanych, jak i do ich powrotu na wolność. To z kolei sprzyja zjawisku, jakim jest stygmatyzacja, obejmująca swym zasięgiem tych, którzy po odbyciu kary pozbawienia wolności na nowo próbują znaleźć swoje miejsce w społeczeństwie. Chcąc zminimalizować jej skutki, istnieje konieczność zwiększenia efektywności resocjalizacji jednostek odbywających karę pozbawienia wolności. Na efektywność procesu resocjalizacji osób skazanych wpływają szczególnie „poznawczo-behawioralne programy resocjalizacyjne; edukacja, trening umiejętności społecznych i praca oraz sprawiedliwość naprawcza" (Opora, 2012).

Podsumując należy podkreślić, że współcześnie resocjalizacja odgrywa znaczącą rolę w procesie powrotu przestępców na drogę akceptowaną społecznie. Jej celem jest dokonanie w skazanym takich zmian, które pozwolą mu spojrzeć na jego przeszłość z innej strony, jednocześnie dokonując także w jego psychice takich zmian, dzięki którym dostrzeże, że w jego obecnym życiu nie ma już miejsca na przeszłość, lecz musi otwierać kolejne drzwi, poszerzać horyzonty 
myślowe, kulturowe, dążyć do bycia lepszym człowiekiem. Należy uświadomić podopiecznym, że ,nie ma żadnej siły poza człowiekiem, która mogłaby za niego rozwiązać dany problem”, że „człowiek musi sam użyć swoich mocy, aby nadać znaczenie swojemu istnieniu, ale jednocześnie [...] konieczne jest wsparcie ze strony innych, którzy potrafią określić sytuację jednostki i pomóc jej zrozumieć aktualny stan rzeczy" (Kieszkowska, 2011). Dzięki takiemu ujęciu skazany zrozumie, że ma problem, który może rozwiązać tylko on sam dzięki swoim chęciom, pracy nad sobą i dobrej woli, jednak są organy, ludzie, którzy są zatrudnieni po to, by mu pomóc, po to, by wspierać go w dążeniu do wyznaczonych celów, żeby pomagać mu i krok po kroku ukierunkowywać. Osoba poddawana resocjalizacji musi uświadomić sobie, że nie tylko ona jedna popadła w konflikt z prawem i jest wiele innych osób, które właśnie w tej chwili - podobnie jak ona - próbują na nowo żyć, lecz życiem właściwym, zgodnie z normami prawnymi i zasadami współżycia społecznego. Podopieczny musi zaufać osobie, która chce mu pomóc, wiedząc, że ma ona stosowną wiedzę, jak to zrobić, doświadczenie oraz że nie traktuje go jako kolejnego „przypadku”, lecz jako kolejnego człowieka, któremu należy pomóc, bo on takiej pomocy oczekuje i chce rozpocząć nowe, dobre życie.

Zdaniem Kazimierza Pospiszyla w pracy resocjalizacyjnej należy na każdym kroku pamiętać o wzbogaceniu procesu resocjalizacji wyzwoleniem nieobcej każdemu człowiekowi umiejętności tworzenia i chęci wypowiadania siebie w inny sposób - i bardziej wszechstronny, i bardziej dogłębny niż popełniane do tej pory przestępstwa, które też stanowią w jakimś stopniu ekspresję nierozwiązanych konfliktów wewnętrznych (Pospiszyl, 1998).

\section{BIBLIOGRAFIA}

BaŁandynowicz, A. (2006). System probacji w Polsce - diagnoza i kierunki zmian w polityce kryminalnej. W: H. MACHEL (red.), Wykonywanie kary pozbawienia wolności w Polsce w poszukiwaniu skuteczności (s. 69-107). Gdańsk: Wydawnictwo Uniwersytetu Gdańskiego.

Bonta, J., Andrews, D.A. (2007). Risk-Need-Responsivity Model for Offender Assessment and Rehabilitation. Ottawa: Correctional Services of Canada.

Chojecka, J. (2013). Kobieta w więzieniu i jej resocjalizacja - zamierzenia a rzeczywistość. Poznań: Wydawnictwo Naukowe UAM.

Encyklopedia popularna PWN (1989). Warszawa: PWN.

HoŁyst, B. (2017). Kryminologiczna ocena granic resocjalizacji. W: T. SoŁtysiaK, M. GoŁemBOWSKa (red.), Resocjalizować, we współczesnej rzeczywistości społecznej? Ale jak? (s. 17). Bydgoszcz: Wydawnictwo UKW. 
IWAŃski, Z.S. (2003). Wprowadzenie do pedagogiki resocjalizacyjnej. Płock: Wydawnictwo Novum.

IWAŃSKI, Z.S. (2017). Etyczny, prawny i religijny wymiar procesu resocjalizacji skazanych. Warszawa: Fundacja „Ubi societas, ibi ius”.

JEDYNAK, T. (2007). Ustawa o kuratorach sądowych - „konstytucja” kuratorskiej służby sądowej. W: K. Jedynak, K. Stasiak (red.), Zarys metodyki pracy kuratora sqdowego (s. 65-66). Warszawa: Wolters Kluwer.

Kieszkowska, A. (2011). Pedagogiczny wymiar probacji wobec osób skazanych warunkowo przedterminowo zwolnionych. Probacja, 4, 95-110.

KonopCZyŃsKi, M. (2006). Metody twórczej resocjalizacji. Resocjalizacja. Warszawa: Wydawnictwo Naukowe PWN.

Konopczyński, M. (2012). Twórcza resocjalizacja. Probacja, 2, 36-37.

Kowalczyk, M.H. (2012). Zabójcy seryjni i seksualni oraz możliwości ich resocjalizacji. Resocjalizacja Polska, 3, 35-53.

Łuczak, E. (2014). W poszukiwaniu dróg skutecznej resocjalizacji. W: E. Łuczak, S. PrzybyLIŃSKi, J. ŻEROMSKA-ChARLIŃSKa (r ed.), Eksplikatywne ujęcie procesu resocjalizacji (s. 23). Olsztyn: Uniwersytet Warmińsko-Mazurski.

ŁUCZAK, E. (2016). Współczesne problemy resocjalizacji penitencjarnej i ich minimalizowanie. Lubelski Rocznik Pedagogiczny, 35 (2), 105-114.

Malec, N. (2017). Prognoza recydywy do roku 2022. W: B. Hołys (red.), Prognozowanie kryminologiczne $w$ wymiarze społecznym. T. 1: Metodologia. Analizy. Tendencje rozwojowe (s. 301-348). Warszawa: Wydawnictwo Naukowe PWN.

Opora, R. (2012). Kierunki współczesnych badań nad efektywnością oddziaływań resocjalizacyjnych. Probacja, 3, 67-81.

Pierzchala, K. (2013). Kapelan więzienny w procesie resocjalizacji penitencjarnej. Toruń: Wydawnictwo Adam Marszałek.

PierzchaŁa, K. (2016). Destygmatyzacja przestępców w świetle Magisterium Kościoła oraz poglądów na resocjalizację. Kraków: Oficyna Wydawnicza „Impuls”.

PierzchaŁa, K. (2017a). Pedagogical and Theological Reflections on the De-Stigmatization Process [Refleksje pedagogiczno-teologiczne nad procesem destygmatyzacji]. Polish Journal of Social Rehabilitation / Resocjalizacja Polska, 13, 17-37.

PierzchaŁa, K. (2017b). Wina - prawo - kara. Prawne i psychopedagogiczne aspekty resocjalizacji penitencjarnej [Fault - Law - Penalty. Legal and Psycho and Pedagogical Aspects of Penitentiary Rehabilitation]. Probacja, 3, 91-117.

PierzchaŁa, K. (2018a). Resocializing Role of Sport and Recreation of Socially Maladjusted People [Resocjalizująca rola sportu i rekreacji osób niedostosowanych społecznie]. W: L. Kataryńczuk-Mania, M. Przybysz-Zaremba, M. Romeris (red.), Health an Interdisciplinary Study [Zdrowie i badanie interdyscyplinarne] (s. 371-386). Lithuania: Mykolas Romeris University in Vilnius.

PierzchaŁa, K. (2018b). Forms of Rehabilitation's Effects Toward Dysfunctional Family [Formy oddziaływania resocjalizującego wobec dysfunkcjonalnej rodziny]. W: M. PRzYBYsz-ZAremba, W. Ziarek (red.), FAMILY. Tasks - Help - Support. Selected Aspects (s. 249-263). Lithuania: Mykolas Romeris University in Vilnius. 
Pospiszyl, K. (1998). Resocjalizacja. Teoretyczne podstawy oraz przykłady programów oddziaływań. Warszawa: Wydawnictwo Akademickie „Żak”.

Przybyliński, S. (2006). Podkultura więzienna - wielowymiarowość rzeczywistości penitencjarnej. Kraków: Oficyna Wydawnicza „Impuls”.

ŚpIewaK, J. (1999). Kurator sqdowy w postępowaniu karnym wykonawczym. Poradnik dla sprawujacych dozory. Warszawa: Wydawnictwo Prawnicze.

\section{WSPÓŁCZESNE PROBLEMY RESOCJALIZACJI}

\section{Streszczenie}

Zagadnienia dotyczące współczesnych problemów resocjalizacji wskazują, że proces resocjalizacji jest bardzo złożony. Czynniki egzogenne i endogenne w dużym stopniu utrudniają podejmowanie działań zmierzających do ponownej socjalizacji osób dotychczas niedostosowanych społecznie. Podkreślić należy, że mimo to resocjalizacja się odbywa i niejednokrotnie przynosi pożądane efekty. Osoby resocjalizujące dokładają wszelkich starań, by pomimo utrudnień, osoby, które są poddawane działaniom resocjalizacyjnym zrozumiały, że tylko życie zgodne z normami prawnymi prowadzi do rozwoju, zadowolenia i sukcesów.

Słowa kluczowe: resocjalizacja; kara pozbawienia wolności; recydywa; zakład karny.

\section{CONTEMPORARY PROBLEMS OF RESOCIALIZATION}

\section{Summary}

Issues related to contemporary problems of resocialization make us realize that the process of resocialization is very complex. Exogenous and endogenous factors make it very difficult to undertake actions aimed at re-socialization of people who have not been socially adapted to date. It should be emphasized that despite this, rehabilitation takes placeand often brings the desired results. Resocializing persons make every effort to ensure that despite impediments, people who are subjected to rehabilitation activities understand that only living in accordance with legal norms leads to development, satisfaction and successes.

Key words: resocialization; imprisonment; recidivism; penal institution. 